\title{
Bioclimatic of mycosis among wild and endemic animals captive-bred at Tsimbazaza Park in the Madagascar
}

\author{
*RAZAFIARISOA Berthine, RAZAIARIVELO Christine, RAMAROMILANTO Boromé \\ Parc Botanique et Zoologique de Tsimbazaza (PBZT) \\ Rue Fernand Kasanga, Tsarafaritra, BP 4096 \\ Antananarivo 101 - Madagascar \\ * Corresponding Author: razafiari4@yahoo.fr \\ DOI: $10.31364 / \mathrm{SCIRJ} / \mathrm{v} 6.111 .2018 . \mathrm{P} 1118581$ \\ http://dx.doi.org/10.31364/SCIRJ/v6.i11.2018.P1118581
}

\begin{abstract}
The Madagascar is renowned as a country with a high endemism Fauna. The island is among the hotspot biodiversity countries. In fact, some infectious diseases are harmful for its wild endemic animals but related information is lacking. This study is carry out to overcome at this deficit. The method of records' ${ }^{6}$ research is used to estimate the incidence of the mycosis among these animals which were captive-bred at the Tsimbazaza Park. Then, a bioclimatic study is done to appreciate the influence of climate on the development of fungal pathogens and its impact on animals. During the period of observations from year 2011 to April 2018, three types of mycosis (ringworm, aspergillosis and candidiasis) are affected twelve animals: three of them are healed and the rest died mostly by sudden death. Aspergillosis was common than the others type of infections. All classes of animals (mammals, aves, reptiles) are concerned with eleven endemic species listed on the red list of International Union for Conservation of Nature (IUCN). Females were more vulnerable than males. The optimum of diseases are located in 2016 and 2017, recorded among the global warmest years. These conditions was favorable both for generating discomfort within the living organisms and for fungus development. Infections were more significant at the two periods of offseason in the Madagascar. These outcomes will help in improving the management of the conservation program by taking into account climate-pathological risks. They may be used too, as eco epidemiology indicators on prevention of the mycosis infections in the Madagascar.
\end{abstract}

Keywords: Bioclimatic, eco epidemiology, hotspot biodiversity, mycosis, Madagascar, wild endemic animals.

\section{Introduction}

The Madagascar's isolation over than millions of years is an ideal condition for the development of a highest endemic biodiversity. The International Conservation has recorded among the Malagasy Fauna: i) 101 endemic primate species and subspecies, (ii) five endemic bird families which represent $51 \%$ of the diversity, iii) 370 reptile species with $90 \%$ endemic, not found nowhere else (Conservation international, 2017). In 2016, the UNEP-WCMC ${ }^{1}$ has classified the island among the hotspot biodiversity countries (MEEF, 2016). In fact, infectious diseases such mycosis are harmful for these wild endemic animals while related information is lacking. This retrospective research aims to fill this gap by estimate the incidence of the mycosis infections among these animals captive-bred at Tsimbazaza Botanic and Zoology Park (PBZT). Then, a bioclimatic study is carried out to appreciate the relationship between climate conditions within discomfort of living organisms and the development of fungal infections. The outcomes of the study will help mainly to improve the conservation program and to prevent mycosis diseases in the Madagascar.

\section{Site and Methods}

\subsection{Site}

The PBZT is positioned at $1261 \mathrm{~m}$ altitude in the capital of the Madagascar. It is set in the sub humid climate stage attenuated by fogs in the dry season (Cornet A., 1974). The Park is assigned for the conservation of endemic species exposed to extinction in their natural local. It participates in the implementation of the national strategies and policies on climate change and biodiversity (MeSupReS, 2015).

\subsection{Methods}

Investigation of the zoo stored data

A research method using zoo records is done (Holly Farmer and al., 2013). The investigation concerned the archives 'information which are stored from year 2011 to April 2018 at the Zoo. They are related to: i) scientific name, ii) sex, iii) clinical data, 
including details of symptoms, treatment given, iv) year of the infection, v) finality of disease: healed or death with the date, vi) the results of post-mortem examination: organs or tissues lesions after dissection observations and laboratory investigations ${ }^{2}$ to specify the kind of mycosis.

\section{Bioclimatic study}

Climate data (temperature and rainfall) from national meteorology office is used to appreciate the relationship of climate on the fungus development and the discomfort of the living organisms. Humidity Index (HI) which measured the effects of combined heat and humidity on the body stress is used to class discomfort of living organisms according its value (Demoulin P., 1998):

- $\quad 20<\mathrm{HI}<29$ : Feeling of well-being

- $\quad 30<\mathrm{HI}<34$ : Feeling more or less uncomfortable

- $\quad 35<\mathrm{HI}<39$ : Sensation of large discomfort. Care or may extend to general feeling of discomfort.

- $\quad 40<\mathrm{HI}<45$ : Danger.

\section{Results and Discussion}

\subsection{Mycosis, species and their IUCN status}

Three kinds of fungal infections are identified to distress wild endemic animals. These are: ringworm, candidiasis and aspergillosis. Twelve (12) species in all classes of animals (reptiles, aves, primate and non-primate mammals) are affected by mycosis. Only one species, Chrysolopus pictus (Chrysolopus $p$.) was not an endemic animal; ten (10) of them are endemic species listed in the International Union for Conservation of Nature's red list (IUCN, 2011). The classes on the red list are following:

- Class in "danger of extinction" (EN): three species (03): Anas bernieri (Anas b.), Circus macrosceles (Circus m.) and Lemur catta (Lemur c.) (Tab.1).

Table 1: Animals in class of danger of extinction (IUCN)

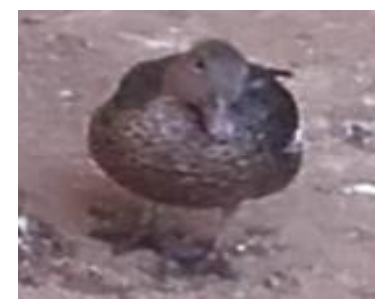

Photo 1 PBZT

Class : Aves

Ordre : Ansériformes

Family : Anatidae,

Species: Anas $b$.

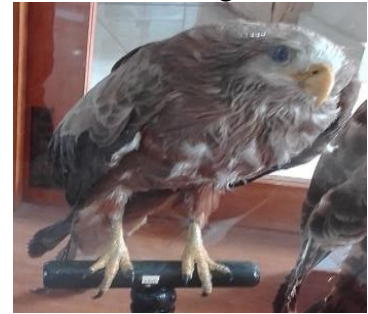

Photo 2 PBZT

Class : Aves,

Order : Falconiformes

Family : Accipitridae, Species: $\underline{\text { Circus } m}$

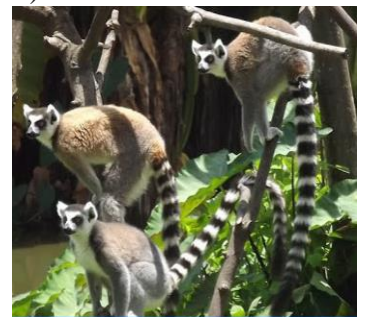

Photo 3 PBZT

Class : Primates,

Order : Lemuriformes,

Family : Lemuridae,

Species: Lemur c.

- Class in «Vulnerable» (VU): four species (04): Eulemur rubriventer (Eulemur $r$.), Cryptoprocta ferox (Cryptoprocta f.), Falculea palliata (Falculea p.), Uratelornis chimaera (Uratelornis c.) (Tab. 2).

Table 2: Animals in class of Vulnerable (IUCN)

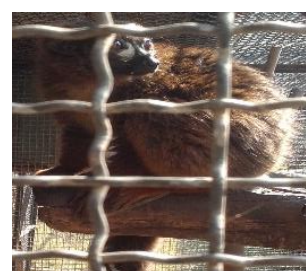

Photo 4 PBZT

Class : Primates

Order : Lemuriformes

Family Lémuridea,

Species : Eulemur $r$.

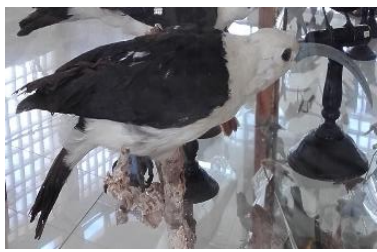

Photo 5 PBZT

Class : Aves,

Order : Passériformes,

Family : Vangidae,

Species: Falculea $p$.

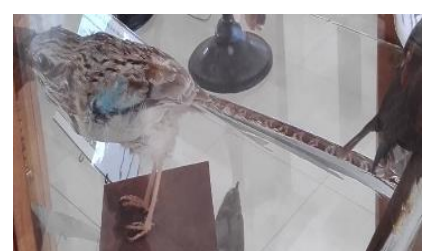

Photo 6 PBZT

Class : Aves,

Order : Coraciiformes,

Family : Brachyptéraciidea,

Species: Uratelornis $c$.

${ }^{2}$ Laboratoire National de Diagnostic Vétérinaire (LNDV) and Laboratoire de l'Institut Pasteur de Madagascar (IPM) www.scirj.org 


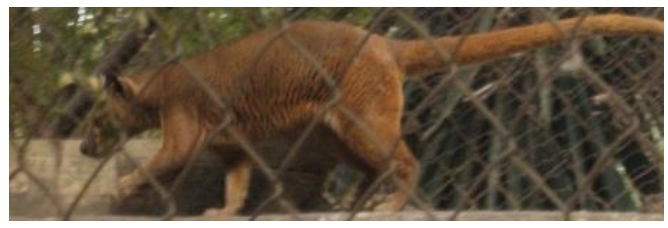

\section{Photo 7 PBZT}

Class : Non-primate mammals

Order : Feliformes,

Family : Eupleridae,

Species: Cryptoproctaf.

- Class in "Newar Threatened" (NT): One species: Lophobis cristata (Lophobis c.) (number=2) (Tab.3).

Table 3: Animal in class of Newar Threatened (IUCN)

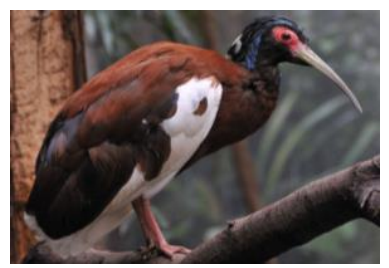

Photo 8 PBZT

Class: Aves,

Order : Pélécaniformes

Family: Threskiornithidea, Species : Lophobis $c$.

- Class in "Least Concern" (LC): two species (02): Crocodylus niloticus madagascariensis (Crocodylus $n$. m.) and Anas platyrhynchos (Anas p.) (Tab. 4).

Table 4: Animal in class of Newar Threatened (IUCN)

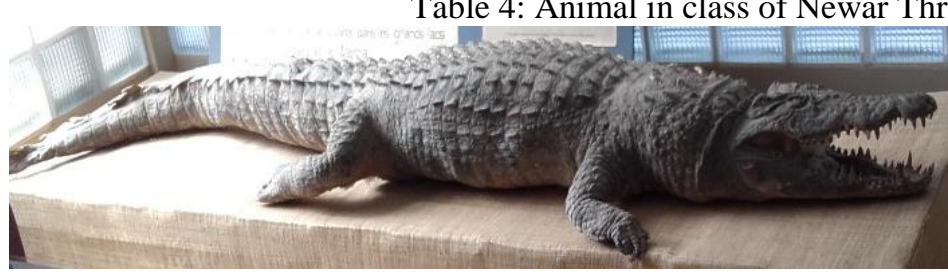

Photo 9 PBZT

Class : Reptiles,

Order : Crocodilians,

Family : Crocodylidae,

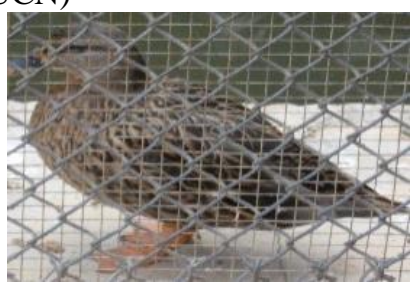

Photo 10 PBZT

Class : Aves

Ordre : Ansériformes

Family: Anatidae,

Species: Anas $p$.

If the ringworm is observed for one animal and the candidiasis disease for two, in opposite, aspergillosis was common among nine animals. Three (03) animals are recovered after treatment: Eulemur $r$. from a ringworm disease and Lophobis $c$. and Chrysolopus $p$. from a light aspergillosis. Nine (09) others was dead with five (05) sudden death.

\subsection{Animals by sex and years of disease}

The Figure1 reports the dispatching of animals by sex within the study years.

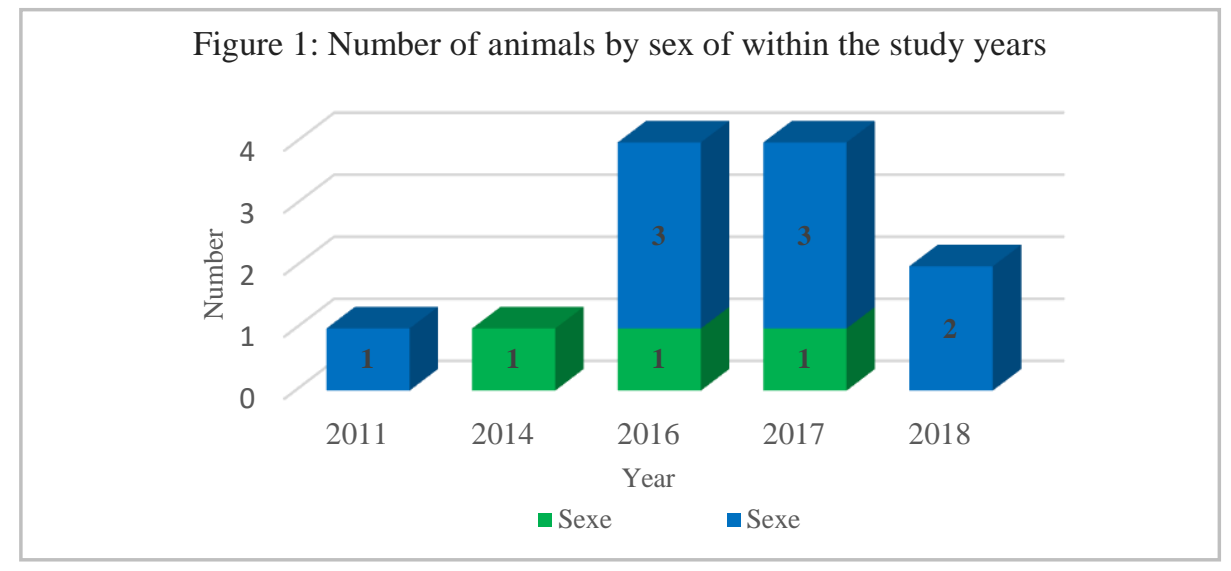


No disease is noticed in years: 2012, 2013 and 2015. The maxima was in the years 2016 and 2017: for 2016: Eulemur $r$., Falculea p., Uratelornis c., Circus m., and for 2017, Chrysolopus p., Lophobis c. $(\mathrm{n}=2)$, Cryptoprocta f.

For the year 2018, two animals (02) were affected: Anas b. and Anas $p$. . Otherwise, two species are concerned by candidiasis: Lemurc. (year 2011) and Crocodylus n. m. (year 2014).

Females were more vulnerable to fungal infections with $9 / 12$ proportion without direct relation with the breeding season.

\subsection{Post mortem lesions}

The following photos are shown some post mortem lesions due to deep aspergillosis and candidiasis with laboratories confirmations.

\section{- Lesions due to aspergillosis}

Photos 10 PBZT: Aspergillosis for Cryptoprocta f.. The clinical symptoms were: Skin diseases at the beginning and after a few days of healing, relapse with weakness, dyspnea and slimming
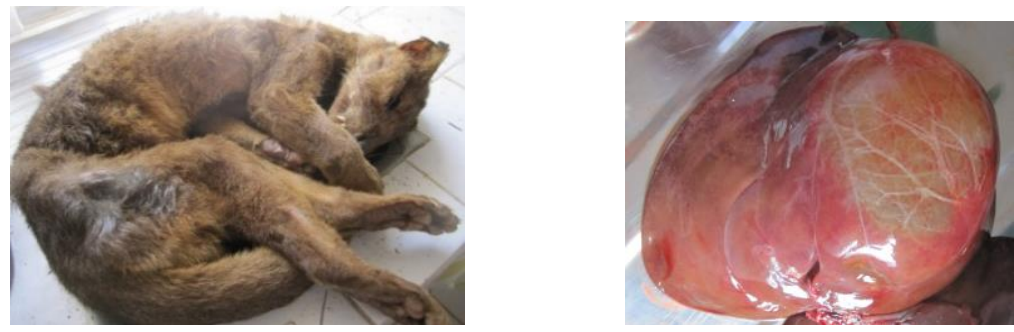

Photos 11 PBZT: Aspergillosis for Anas $b .$. No clinical signs following but sudden death

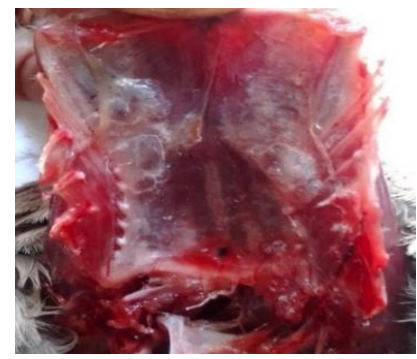

Elevation of infected sternum, bronchial bifurcation become umbilicated with granulomas in the lungs

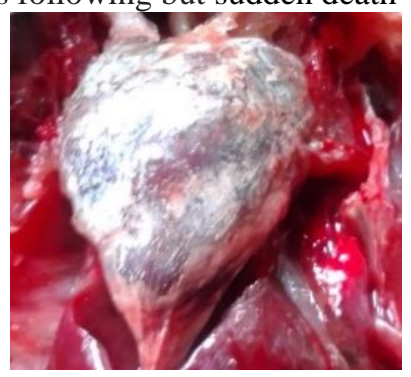

Granulomas on the tissues of the heart

Photo 12 PBZT: Candidiasis for Crocodylus n. m.. The clinical symptoms were deep abatement followed by sudden death

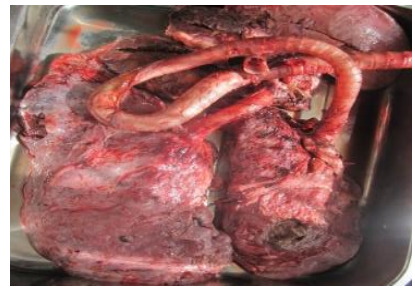

Hemorrhagic lung associated with pulmonary edema

Photos 13 PBZT: Candidiasis for Lemur c.. The clinical symptoms were: depilation and chronic inflammatory skin lesions followed by degeneration
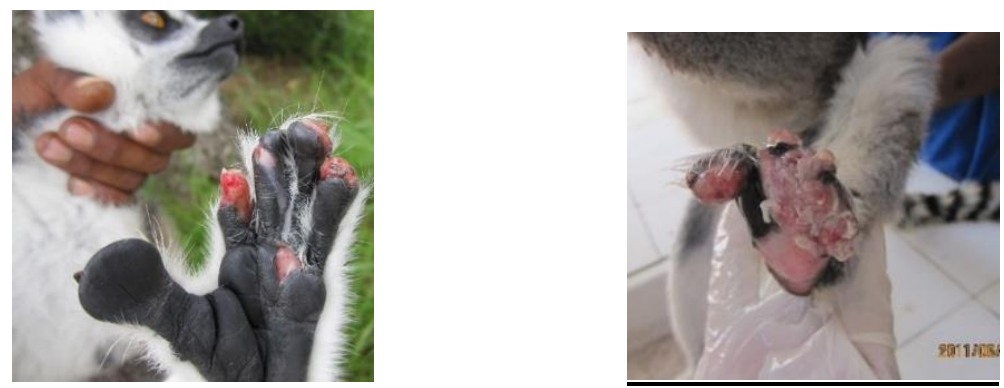


\subsection{Mycosis infections and climate data}

Warm temperatures with abundant rainfall are a favorable climate for the reproduction of fungal. Diseases are prevailing during the months of the two periods of offseason in the Madagascar: i) first offseason: between February to the end of April or the beginning of May and ii) second offseason: from September to beginning of October (Fig. 2).

Figure 2: Distribution of mycosis during the study period

\begin{tabular}{|c|c|c|c|c|c|c|c|c|c|c|c|c|}
\hline \multirow{2}{*}{ Year } & \multicolumn{12}{|c|}{ Months } \\
\hline & $\mathrm{J}$ & $\mathrm{F}$ & M & A & M & $\mathrm{J}$ & $\mathrm{J}$ & A & $\mathrm{S}$ & $\mathrm{O}$ & $\mathrm{N}$ & $\mathrm{D}$ \\
\hline 2011 & & & & & & & & & & & & \\
\hline 2014 & & & & & & & & & & & & \\
\hline 2016 & & & & & & & & & & & & \\
\hline 2017 & & & & & & & & & & & & \\
\hline 2018 & & & & & & & & & & & & \\
\hline
\end{tabular}

The death on July of Lemur $c$. is an exception because it is due to a long illness.

The common characteristics of the climate (temperature, rainfall) for each months of the study period, compared to the reference period 1961/1990 in the Madagascar were: i) minima temperatures higher than the average temperature, ii) an overall increase of maxima temperatures except for July 2014, and iii) rainfall with turbulences. These situations confirmed the effectiveness of climate 'study change in 2008. In fact, it is projected that the changing would be expressed mainly in rise of the extreme temperatures (minima and maxima) and a disorder in the rainfall (DGM, 2008).

In addition, the results are reliable with the observations of the global warming about the warmer year's records from 1880 to 2017, for the years 2016, 2017 and 2014 (Global Temperature Anomalies, 2018) (Tab. 5).

Table 5: Comparison of average-differences of the temperatures at the national and global levels on the warmer years

\begin{tabular}{ccc}
\hline Years & National average-deviation & Global average-deviation \\
\hline 2016 & $+1,36^{\circ} \mathrm{C}$ & $+1,25^{\circ} \mathrm{C}$ \\
2017 & $+1,07^{\circ} \mathrm{C}$ & $+1,13^{\circ} \mathrm{C}$ \\
2014 & $+0,83^{\circ} \mathrm{C}$ & $+0,88^{\circ} \mathrm{C}$ \\
\hline
\end{tabular}

According the Global Climate Risk Index 2015, the Madagascar is ranked as the 8th most country affected by climate change with vulnerability risk (DGGFPE/MFB, 2016).

The measure of Humidity Index ( $\mathrm{IH})$ has confirmed the relationship between the discomforts of the living organism within the development of the fungi pathogens (Tab. 6). 
Table 6: Degree of discomfort measured by Humidity Index (IH) for each species at month corresponding on healed or death

\begin{tabular}{|c|c|c|c|c|}
\hline IH value & Class of incomfort & $\begin{array}{c}\text { Species Healed }(\mathrm{H}) \text { or } \\
\text { death }(\mathrm{D})\end{array}$ & Date & Type of mycosis \\
\hline 26 & \multirow{3}{*}{ Well-being } & Falculea p. (D) & May 2016 & \multirow{2}{*}{ Aspergillosis } \\
\hline 28 & & Circus m. (D) & September 2016 & \\
\hline 26 & & Lemur c. (D) & July 2011 & Candidias \\
\hline 30 à 31 & \multirow{3}{*}{$\begin{array}{l}\text { More or less } \\
\text { uncomfortable }\end{array}$} & Crocodylus n. m. (D) & September 2014 & \multirow{2}{*}{ Aspergillosis } \\
\hline 34 & & Anas b. (D) & April 2018 & \\
\hline 34 & & Eulemur $r .(\mathrm{H})$ & April 2016 & Ringworm \\
\hline 35 à 36 & $\begin{array}{l}\text { Large discomfort } \\
\text { extend to general } \\
\text { feeling of } \\
\text { discomfort. }\end{array}$ & Cryptoprocta f. (D) & October 2017 & \multirow[t]{2}{*}{ Aspergillosis } \\
\hline 37 à 38 & $\begin{array}{l}\text { Large discomfort. } \\
\text { Care }\end{array}$ & Uratelornis c. (D) & March 2016 & \\
\hline 37 à 38 & $\begin{array}{l}\text { Large discomfort. } \\
\text { Danger }\end{array}$ & Anas p. (D) & February 2018 & Candidiasis \\
\hline 39 à 40 & \multirow{3}{*}{$\begin{array}{l}\text { Large discomfort } \\
\text { extend to general } \\
\text { feeling of discomfort }\end{array}$} & Chrysolopus p. $(\mathrm{H})$ & February 2017 & \multirow[t]{3}{*}{ Aspergillosis } \\
\hline 39 à 40 & & Lophobis c. $(n=2)(\mathrm{H})$ & February 2017 & \\
\hline 39 à 40 & & Cryptoproctaf. (D) & October 2017 & \\
\hline
\end{tabular}

The mycosis disease in well-being class $(\mathrm{HI}=26$ or 28$)$ requires others considerations as habitat, food or captivity than only climate stress.

Global warming had significant impacts both on plants (Andriamalalanirina F., 2018) and on animals in the Madagascar.

\section{CONCLUSIONS}

Three kinds of mycosis (ringworm, aspergillosis, candidiasis) are affected all the classes of wild endemics animals captive-bred in the Tsimbazaza Park. Aspergillosis was the common fungal infections. Most species were on the IUCN red List. Females were more vulnerable than males mostly during the two periods of offseason in the Madagascar. Moreover, the maxima of the fungal infections are corresponded with the global hottest years. Climate stress had an impact both on animal's body discomfort and on the development of fungal pathogens.

The outcomes will help to improve the management of the conservation program by taking into account the climate-pathological risks. They may be used too as eco-epidemiology indicators on prevention of mycosis in the Madagascar.

\section{REFERENCES}

Andriamalalanirina. P., 2018 : Risques climatiques, vulnérabilités et mesures d'adaptation pour une filière cacao durable dans la zone du Sambirano. Séminaire international participatif sur la filière Cacao, Helvetas.

Conservation international, 2017: Valeur de la biodiversité.Madagascar. https://www.conservation.org/global/madagascar/initiatives/Pages/biodiversite.aspx

Cornet A., 1974 : Essai se cartographie bioclimatique à Madagascar. Notice explicative $\mathrm{N}^{\circ} 55$. Laboratoire de botanique. Mission ORSTOM de Tananarive, ISBN 2-7099-0339-3, 28, pp : 21-24.

Demoulin P., 1998 : Température et humidité relative, http://www.astro.ulg.ac.be/ demoulin/humidex.html, Dernière mise à jour : 14 juin 1998 
Direction Générale de la Gestion Financière du Personnel de l'Etat (DGGFPE)/ Ministère des Finances et du Budget (MFB), 21 septembre 2016, http://www.dggfpe.mg/index.php/2016/09/21/changement-climatique-madagascar-troisieme-paysmonde-plus-expose-aux-risques-climatiques/

Direction Générale de la Météorologie, 2008. Le changement climatique à Madagascar. Trust Fund for Environmentally and Socially Sustainable Development (TFESSD), Bank Netherlands Partnership Program, Banque Mondiale, Université de Cap Town, 32, pp : 13-19.

Global Temperature Anomalies, 2018; Station Temperature Index in 0.01 degrees Celsius, base period: 1951-1980. Sources: GHCN-v3 1880-04/2018 (meteorological stations only. Using elimination of outliers and homogeneity adjustment. Notes: 1950 DJF = Dec 1949 - Feb 1950. https://data.giss.nasa.gov/gistemp/tabledata_v3/GLB.Ts.txt

Holly Farmer and al., 2013. Chapter 7: Introduction to Research Using Zoo Records. In: Handbook of Zoo Research, Guidelines for Conducting Research in Zoos: London. British and Irish Association of Zoos and Aquariums (BIAZA), 216, pp: $80-94$.

Ministère de l'Environnement, de l'Écologie et des Forêts (C) MEEF 2016: http://www.ecologie.gov.mg/biodiversite-demadagascar/

Ministère de l'Enseignement Supérieur et de la Recherche Scientifique (MeSupReS), 2015. Plan Directeur de la Recherche sur l'environnement lié au changement climatique 2015-2019, Madagascar, pp 68.

IUCN, 2011 : Biodiversité : la liste rouge 2011 de l’UICN recense 25000 espèces menacées. Publié le 17 novembre 2011 ; https://envi2bio.com/2011/11/17/liste-rouge-especes-menacees-2011/ 